PALEO

Revue d'archéologie préhistorique

27 | 2016

Varia

\title{
From France to Saxony - Painted pebbles from Le Mas d'Azil (Ariège) in the archaeological collections from Saxony
}

Johann Friedrich Tolksdorf, Harald Floss and Ingo Kraft

\section{OpenEdition}

\section{Journals}

Electronic version

URL: http://journals.openedition.org/paleo/3297

DOI: 10.4000/paleo.3297

ISSN: $2101-0420$

Publisher

SAMRA

\section{Printed version}

Date of publication: 30 December 2016

Number of pages: 297-305

ISSN: $1145-3370$

Electronic reference

Johann Friedrich Tolksdorf, Harald Floss and Ingo Kraft, « From France to Saxony - Painted pebbles from Le Mas d'Azil (Ariège) in the archaeological collections from Saxony », PALEO [Online], 27 | 2016, Online since 01 June 2018, connection on 07 July 2020. URL : http://journals.openedition.org/paleo/ 3297 ; DOI : https://doi.org/10.4000/paleo.3297

This text was automatically generated on 7 July 2020.

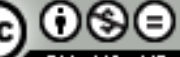

PALEO est mis à disposition selon les termes de la licence Creative Commons Attribution - Pas d'Utilisation Commerciale - Pas de Modification 4.0 International. 


\title{
From France to Saxony - Painted pebbles from Le Mas d'Azil (Ariège) in the archaeological collections from Saxony
}

\author{
Johann Friedrich Tolksdorf, Harald Floss and Ingo Kraft
}

1 The first research into the Palaeolithic in Saxony was strongly influenced by comparable work carried out in France. At the beginning of the $19^{\text {th }}$ century, the discovery and the systematic study of karstic deposits raised an increasing number of questions regarding Palaeolithic cultures, in the research domain as well as among the general public. In this way, the work of Charles Darwin "On the origin of species" initiated discussions focusing on the chronological and qualitative dimension of human creation, which had received little attention up until then. At that time, the French sites were the main centre of interest; which is why collectors channelled their efforts in this direction (Kraft 2010). This interest triggered a thriving trade in Palaeolithic remains. Subsequently, many of these private collections formed the basis of public collections. The prehistoric collection of Dresden, which was inaugurated in 1874 as part of the Royal Museum of mineralogy and geology, and which exposed remains and replicas from French sites in Zwinger Palace from 1892 onwards, is a typical example of this period (Schachtmann 2010). The collection owes its existence to influences from France, as the first curator of the collection, Hanns Bruno Geinitz (1814-1900), was among the admirative visitors of the universal exhibition in Paris in 1867, and in particular the recently discovered Palaeolithic remains (Coblenz 2000).

2 The acquisition of the collections of this museum owes a great deal to the "ISIS" Society of Natural Sciences, founded in 1833, which organized a series of conferences on prehistory from 1870 onwards (Coblenz 1993). In this society, the main representatives of the budding domain of archaeological research in Saxony met up and established strong connections with the central figures of French prehistoric research. For example, these personal links were set up, among others, by Ida von Boxberg, the first 
Saxon archaeologist (Mélard and Krabath 2005; Herrmann and Krabath 2013). She was personally known by the protagonists of French Palaeolithic research as a participant in excavations in France where she acquired many remains during her study missions, which reached the collections of Dresden after her death. A prehistory conference by the ISIS society in 1882 shows how important the French approach was for Palaeolithic research in Saxony, which was just beginning at that time. Hanns Bruno Geinitz gave a conference entitled: "The current state of prehistoric research in France and Germany", in which he reviewed recent progress in French research and tried to compare it with research in Germany in order to draw up a programme of prehistoric research activities in the latter country (Geinitz 1882).

3 The presence of Palaeolithic remains from France (for example, Saint-Acheul, Abbeville, Grotte Margot) is also perceptible in the catalogue of the Dresden collection, established by Johannes Deichmüller (1854-1944). This intensive trade of archaeological objects on a European scale is also responsible for the arrival in Dresden of a remarkable batch of pieces from the Mas d'Azil Cave. In the supplement to the catalogue entitled "Enrichissement de la collection préhistorique 1889 à 1930 - Enrichment of the prehistoric collection, 1889 to 1930", we observe the mention for the year 1899, of " 31 galets peints de la grotte du Mas d'Azil, Dépt. Ariège, France - 31 painted pebbles from Le Mas d'Azil Cave" (fig. 1B). The provenance is indicated as "E. Piette de Rumigny", showing a clear attribution to one of the most emblematic, but also problematic collections in terms of authenticity: the painted pebbles from Le Mas d'Azil. The absolute certainty on the provenance of these pieces comes from the records of the sessions of the ISIS society, which state, for the $18^{\text {th }}$ January 1900: "Prof. Dr. J. Deichmüller presents and describes a number of painted pebbles from the Mas d'Azil Cave in the Pyrenees, which were offered to the Royal Prehistoric Collection of Dresden by Mr. Ed. Piette-Rumigny".

The intensive exchanges with French Palaeolithic research during the $19^{\text {th }}$ century contrast strongly with the situation in the $20^{\text {th }}$ century, which is marked by a concentration of work on Saxon sites and the supply of collections by exclusively autochthonous remains. This new direction is influenced by political and ideological modifications, among others, and by rivalry between the German Empire of 1871 and France, culminating in the two world wars and resulting in the rupture of many scientific contacts. An anecdotal counterpoint to this general evolution is given, from 1940 to 1943 , by the study of prehistoric sites by French prisoners of war, as part of the "l'oflag IV D Elsterhorst (Nardt)", near Hoyerswerda (Saxony) (Groupe d'Études Préhistoriques d'Elsterhorst 1950).

5 After 1945, the links between prehistorians from the Federal Republic of Germany and French prehistoric research developed in a more satisfactory way, but scientific exchange with France was particularly difficult for researchers working in institutions in East Germany (Gramsch 2010). Against this political background, the collections from the parts of the German Reich occupied by the Soviet Union were also left out of international research. This "amnesia" also had many consequences for the remains from the Dresden collections, which was severely damaged during the Second World War, as is clearly shown by the remains from Le Mas d'Azil. When Claude Couraud undertook a review of painted pebbles in 1985, the Le Mas d'Azil site catalogue practically only comprised collections from France and England (Couraud 1985). Meticulous addenda by Paul Bahn (Bahn, Cole and Couraud 1987) revealed several additional painted pebbles from American collections, but the Dresden batch was 
totally overlooked, which shows the extent to which the early collections from the centre and the east of Germany were ignored by French Palaeolithic research. The aim of this article is thus to present the Mas d'Azil painted pebbles from the Dresden collection, which remains virtually unknown in France today. In order to understand the extent to which the decorated pebbles from this site were scattered, and the complications linked to the authenticity of some collections due to forgeries, it is fitting to first of all briefly retrace the complicated history of research at Le Mas d'Azil.

Figure $1 \mathrm{~A}$ - Watercolour by Ida von Boxberg from 1885, showing the stratigraphy of the Grotte de Thévalles. B: Extract of the catalogue of the royal prehistoric collection of Dresden, indicating the entry of 31 painted pebbles from Le Mas d'Azil, dated to the $21^{\text {st }}$ of September 1899, and indicating E. Piette as the donator of these pieces.
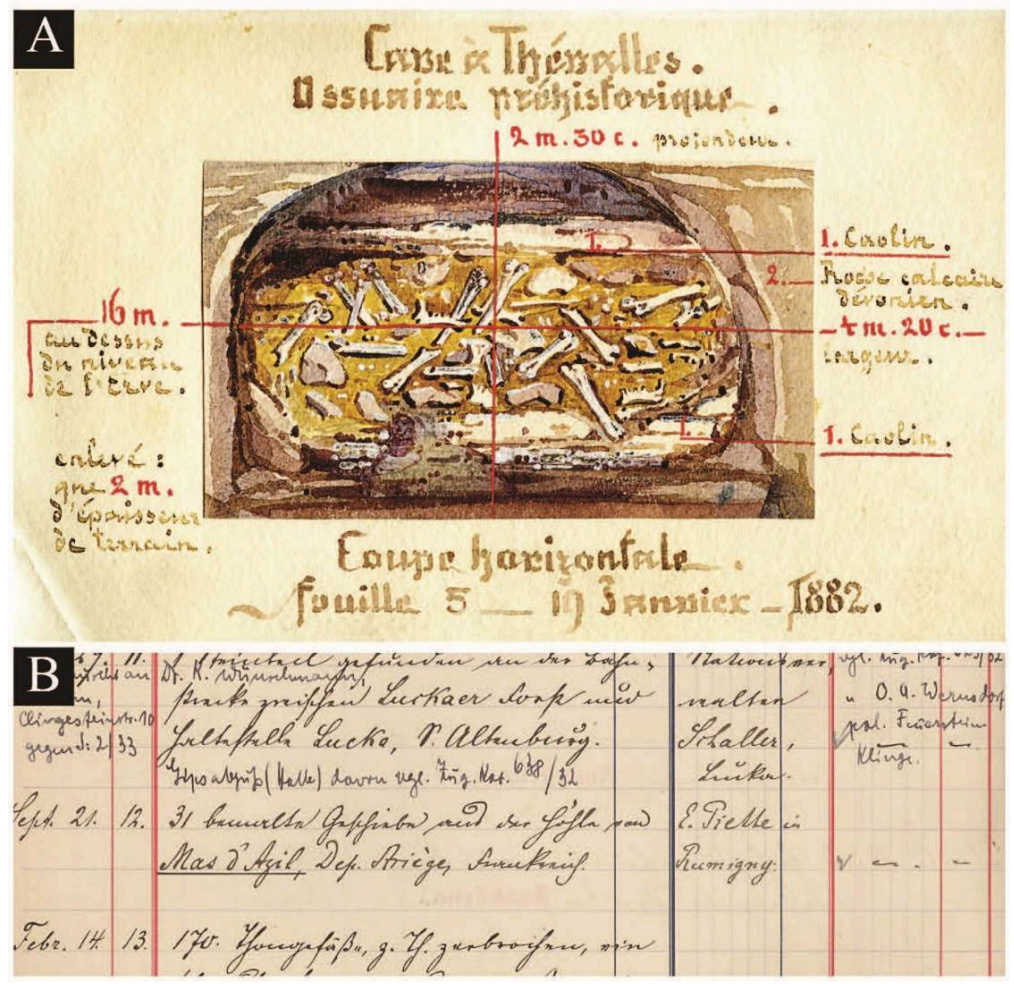

\section{The site}

The Ariège archaeological site of Le Mas d'Azil is a large cave with the Arise running through it, located on terraces on both sides of the river. Following the discovery of bones as part of road construction, Édouard Piette (1827-1906) conducted excavations there in 1887 and seemingly until 1889 (Kegler 2007). Edouard Piette was familiar with the notion of stratigraphy and type fossils and distinguished a thick "transition" level between three Magdalenian levels, separated by flood deposits, and a Neolithic level. For him, this series of deposits represented the filling corresponding to the lacuna existing at that time between the Palaeolithic and Neolithic cultures. This level was characterized by a temperate fauna and flora. During a more detailed subdivision, he distinguished a more recent stratigraphic phase in this transition level, with a high proportion of shells and molluscs (snail layer), and an older phase, containing painted pebbles (layer with coloured pebbles). Edouard Piette introduced the term "Azilian" for 
this phase between the Magdalenian and the Neolithic, for which the painted pebbles were a defining characteristic (Piette 1895, Kegler 2007). In another publication (Piette 1896), the author describes these objects and compares them to an alphabet, with a communication function.

7 From an archaeological point of view, the rest of the research in the cavity is less encouraging (Kegler 2017). The site clearly gained public interest and attracted scientific personalities, such as Henri Breuil, for example (excavations 1901-1902), but at the beginning of the $20^{\text {th }}$ century, the site was progressively abandoned and affected by various clandestine and disorganized activities. In the review Nature, a contribution in 1926 describes the unacceptable state of the site: "Practically there is no control, no protection and no organised excavation whatever at Mas d'Azil. There are masses of valuable material, but none of it is being worked at properly. Much of it, I fear, is being wasted and muddled up. There is a "guide", a pleasant untrained man, who pokes about in the caves, digs out bones which, as he remarks, fall to pieces, and presents the casual visitor with teeth or flint implements he has found in his own researches. He has no regular salary. He has to supplement his fees and tips by other work. Occasionally, isolated individuals obtain permission from the municipality and prod in the rocks and extract this or that and publish their "results", according to their lights. There is a small useless museum without labels or arrangement at the Mairie." (Well 1926). We have to wait until 1935 for new excavations by Saint-Just and Marthe Péquart, which continue until 1944. However, the documentation from these works is very incomplete (Kegler 2007). After the Second World War, security work was carried out on the deposits, under the guidance of André Alteirac, which gave rise to more excavations, unfortunately unpublished. In sum, the difficult research history and the scattering of the remains towards other collections complicated a full study of this site (Kegler 2007).

\section{Painted pebbles - objects sought out by collectors and forgers}

In spite of these problems, Le Mas d'Azil acquired a reputation as a transition site, arousing the interest of museums and collectors who wished to acquire objects from this site, thereby generating an intensive activity of exchange and acquisitions. The painted pebbles were the main reason behind this interest and have been at the centre of many improbable interpretations since their discovery. J. Deichmüller cites for example, for the objects from Dresden, in a presentation to the ISIS society in 1900, the interpretations of E. Piette, for whom these objects represented images of the sun, trees and very early systems of counting and writing. Today, the range of interpretations includes a proto-writing system (Piette 1896; 1904), their use as objects for worship, in much the same way as the Australian "Churingas" (Cook 1903), pawns for a game, art for art's sake (Mallery 1893; Péquart and Péquart 1936), and a cyclical representation of a calendar (Bahn and Couraud 1984, Couraud 1985). The enigmatic nature of these pebbles made them ideal objects for collections and exhibitions at the turn of the $19^{\text {th }}$ and $20^{\text {th }}$ centuries, when the aim was to present new categories of surprising objects. These circumstances contributed to the muddled and non-recorded distribution of a lot of these remains. The works of Claude Couraud (1985) revealed the extent of the dispersal of these objects, bringing together 1400 items from about twenty different museums, mainly in France and England. This list was subsequently extended by the 
presentation of additional objects from France (Couraud and Alteirac 1990, 1993; Alteirac and Couraud 1996) (fig. 2A, 2B). Several objects were even found in America (Bahn et al. 1987) and Zimbabwe. But it was not possible, at that stage, to take into consideration the collections from the ex-Eastern block. The objects purchased by the museum of prehistory and protohistory in Berlin in 1929 (Unverzagt and von Jenny $1935,4)$ and those from Dresden thus eluded him. The number of 1619 painted pebbles counted from Le Mas d'Azil (Alteirac and Couraud 1996) therefore only represents a minimum quantity.

9 A major result of Claude Couraud's study is the observation of a high, but variable rate of forged objects, depending on the collections (fig. 4). The criteria for the identification of these modern counterfeits are the use of pigments unknown at the site, uncoherent stylistic representations and the use of secondary fragmented surfaces for painting. Other pebbles turned out to be clearly authentic, as they are covered by a post-depositional calcareous crust. But in between these two categories, there are a lot of ambiguous cases, where the attribution only tends towards the real and the forged. Claude Couraud showed statistically that the choice and the composition of the signs are not random, although he did not observe all of the theoretically possible combinations. It also seems that some of the signs are quantitatively predominant (for example, signs 21 or 29 ).

By summarizing the results of all of the collections studied by Claude Couraud (fig. 3), we observe a considerable rate of false objects from the Piette series. We discern a correlative trend between the phases of increased popularity of the site and most of the forgeries, but in spite of that, we cannot deny that the first forgeries date to the Piette excavations. The custom of paying workers for the discovery of spectacular objects undoubtedly led to the production of forgeries.

\section{The painted pebbles from the Dresden collection}

11 Today, the archaeological collections from Saxony contain 32 painted pebbles from Le Mas d'Azil, 31 of which are from the 1899 collection. The inventory established after the Second World War contained 31 items, divided into two batches (28 plus 3). In 1959, two of these pebbles (fig. 4, inventory numbers ID 000277348 and 00301207) were lent to the study collection of the Humboldt University in Berlin, and came back to Dresden in 2010. Miraculously, the 1890 inventory lists a $32^{\text {nd }}$ object, for which the internal numbering suggests that it comes from the Hauser, Wilke and Staffel collections. This points to an acquisition after 1925. It is probable that this object was sold to the museum by the German-Swiss antiques dealer Otto Hauser. The latter was a controversial figure, known for the systematic traffic of French prehistoric remains, and also an exemplary figure of the rupture between French and German archaeology generated by the First World War (Drößler and Freyberg 2001). The object in question shows, unlike the others, that colour is spread onto a concretion crust. The pattern itself, made up of simple red bands, is not suspicious, but this observation points towards a forgery. This object has thus been excluded from the corpus of painted pebbles from 1899. 
Figure $2 \mathrm{~A}$

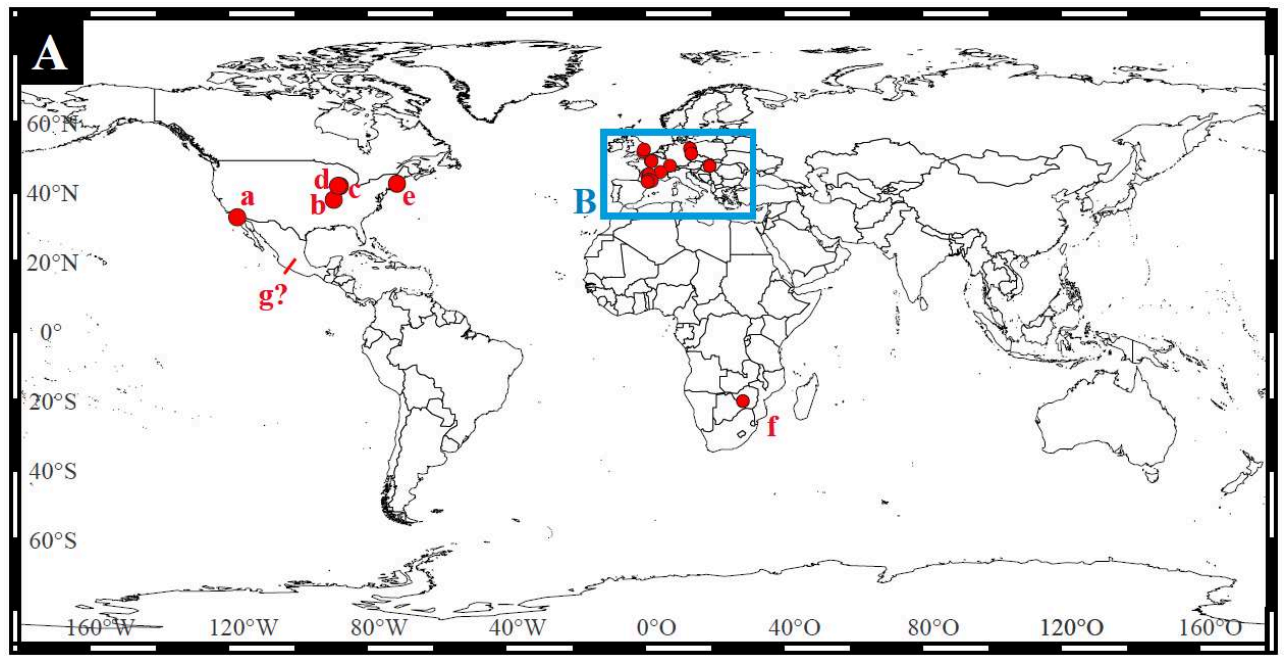

Extra-European collections containing painted pebbles from Le Mas d'Azil, from Bahn et al. 1987: a: Museum of San Diego; b: Logan Museum of Anthropology at Beloit; Murphysboro (White 1992); c: Field Museum of Chicago/ University of Chicago; d: Saint Procopius College, Lisle; e: Peabody Museum of Archaeology and Ethnology at Harvard, Cambridge; f: National Museum of Rhodesia (today National Museum of Zimbabwe); g: Ioan Mexico.

Figure 2 B

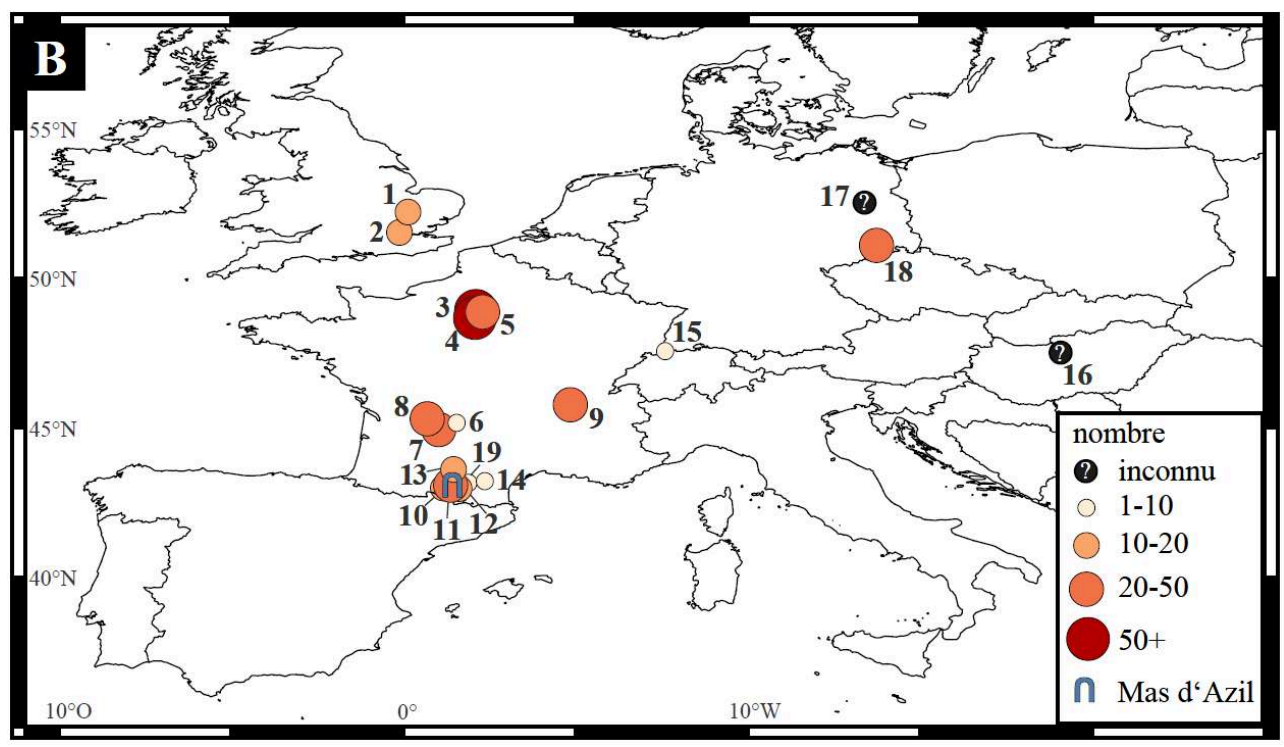

Collections of painted pebbles from Le Mas d'Azil in Europe after Couraud (1985): 1: Museum of Archaeology and Anthropology, Cambridge; 2: British Museum, London; 3: Musée d'Archéologie nationale, Saint-Germain-en-Laye; 4: Musée de l'Homme, Paris ; 5: Institut de Paléontologie humaine, Paris; 6: Musée E. Rupin, Brive; 7: Musée national de Préhistoire, Les Eyzies-de-Tayac; 8: Musée d'art et d'archéologie du Périgord, Périgueux; 9: Musée d'histoire naturelle - Guimet, Lyon; 10: Domaine de Pujol, Saint-Girons; 11: Musée de la Préhistoire, Le Mas-d'Azil; 12: Musée départemental de l'Ariège, Foix; 13: Musée d'Histoire naturelle de Toulouse, Toulouse; 14: Musée des Beaux-arts, Carcassonne; 15 Museum der Kulturen, Basel; 16: Magyar Nemzeti Museum, Budapest; 17: Museum für Vor- und Frühgeschichte, Berlin (Unverzagt/von Jenny 1935); 18: Königliche Prähistorische Sammlung/AAS, Dresden; 19: Sammlung Pouech, Pamiers (Alteirac/Couraud 1996)

12 The Dresden series, with 31 pebbles, is one of the largest sets of painted pebbles from Le Mas d'Azil in the world (fig. 3). In addition, it is one of the rare series directly attributable to the archaeological works of the discoverer Edouard Piette. The patterns 
represent parallel bands, alignments of dots, crosses, straight lines along the long axis of the pebbles, as well as lateral digital imprints. These patterns are perfectly integrated in the known range of types for this site. From a technological and stylistic point of view, no argument can be advanced against the authenticity of these painted pebbles.

Figure 3 - Percentage of forgeries following estimations made by C. Couraud (Couraud 1985; Bahn et al. 1987; Couraud/ Alteirac 1990; Alteirac/Couraud 1993; 1996). The counts refer to the numbers of the collections (see fig. 2).

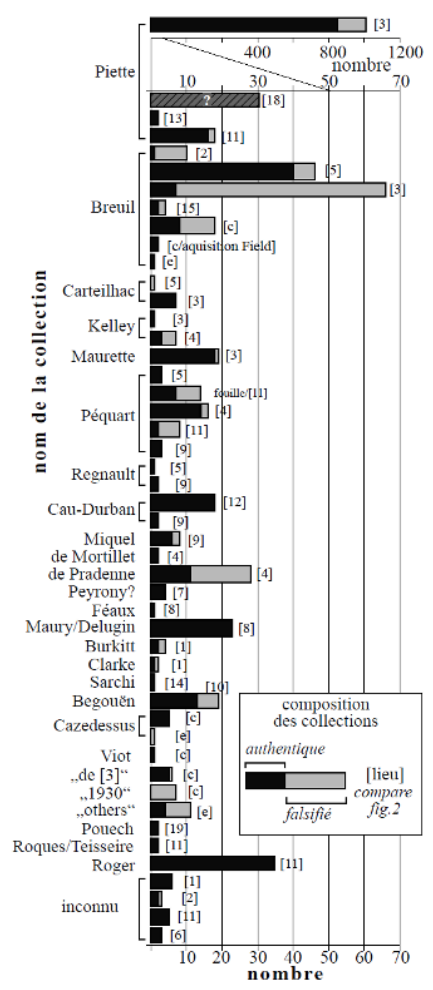

13 Thanks to the investigation by C. Couraud (1985), which brought to light the divergent rates of forgeries in the different collections, today, we can reconstruct several of the routes by which these forgeries were introduced. The records of Edouard Piette show that the excavation workers, in the specific context of this period, earned bonuses for the discovery of particular remains (Kegler 2007- p. 21). This type of situation may have incited the workers to forge pebbles directly at the excavation. This type of behaviour has also been observed at other excavations from that period, like for example at Kesslerloch near Thayingen (Lindenschmit 1876). However, the variation in the number of forgeries in the different collections points to another hypothesis, whereby the forgeries would not have been produced at the excavation, but subsequently during the complex process of setting up and acquiring collections. For the Dresden collection, the direct origin from E. Piette, and the criteria established by C. Couraud, do not provide any evidence of the presence of forgeries. The layer of pigments is pasty and regular and never covers the more recent chips on the pebbles. The remains of a silty deposit, as well as micro charcoals, are observed in the cracks, which coincides with the descriptions of the archaeological level in question (Kegler 2007 - p. 57 and following).

The systematic study of this series of painted pebbles is far from complete. As well as the undeniable scientific interest, these pebbles from Le Mas d'Azil are a good 
illustration of how German prehistoric research was fascinated by the abundant French sites. The main aim of this contribution is to raise awareness of the existence of the objects from Dresden, which are virtually unknown in their country of origin. In 2004, the objects were included in the permanent exhibition of the Staatliches Museum für Archäologie Chemnitz (SMAC) (fig. 5), in a showcase focusing on the history of archaeological research in Saxony. The showcase also featured an old suitcase, the symbol of the enthusiasm of Ida von Boxberg, and her journeys among the prehistoric sites of France.

Figure 4 - The painted pebbles of Le Mas d'Azil from the archaeological archive of Saxony with their inventory numbers and classified according to the different depicted themes. The piece 00089758 is probably not part of the collection from 1889 (E. Piette), but belongs to a more recent museum entry, without a reliable origin.

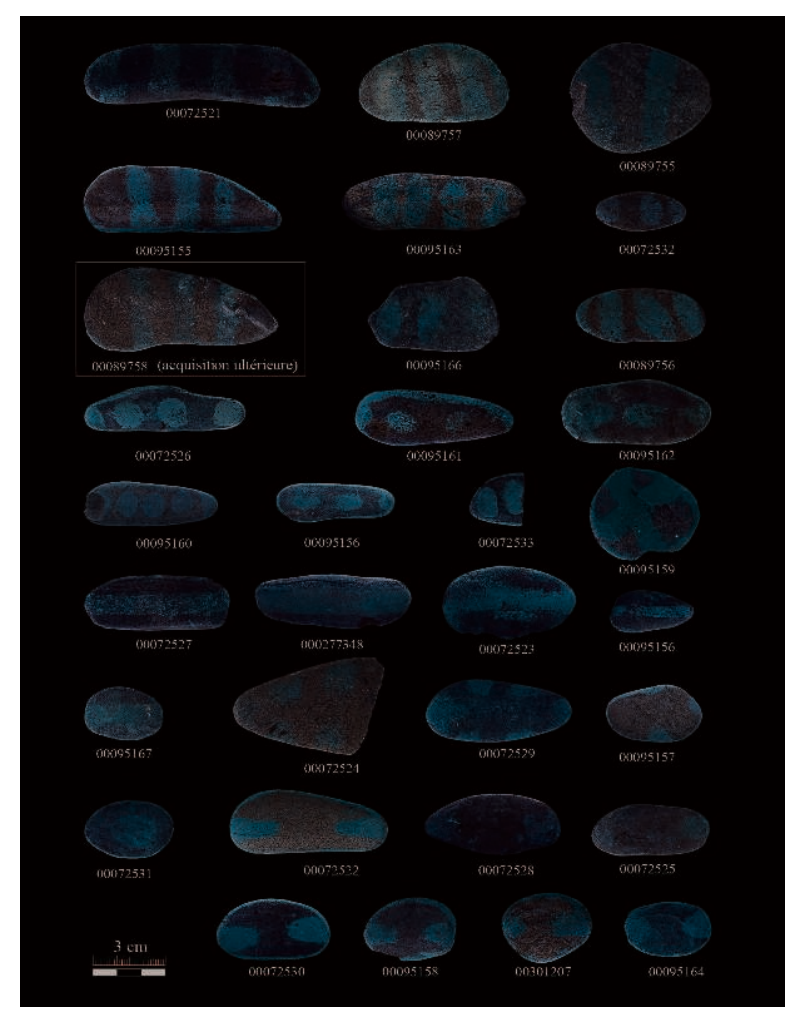


Figure 5 - The current presentation of the painted pebbles from Le Mas d'Azil in the Staatliches Museum für Archäologie Chemnitz.

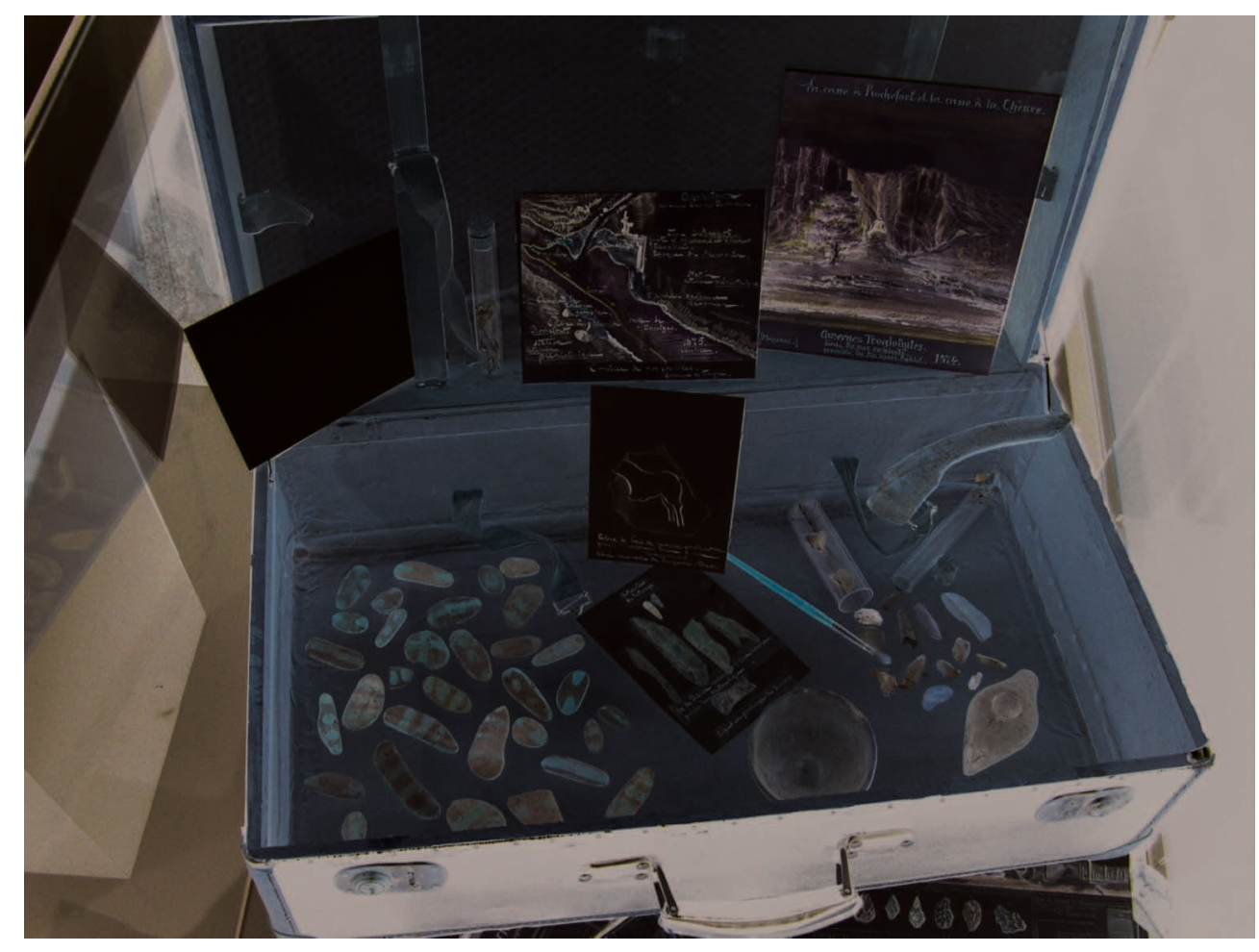

\section{BIBLIOGRAPHY}

\section{Bibliographic references}

ALTEIRAC A., COURAUD C. 1996 - Des galets peints dans la collection Pouech. Bulletin de la Société préhistorique de l'Ariège 51, 1996, 129-132.

BAHN P.G. 1984 - Bahn How to spot a fake azilian pebble. Nature 308, 1984, 229.

BAHN P.G., COLE G.H., COURAUD C. 1987 - Les galets peints du Mas-d'Azil déposés dans les musées des Etats-Unis. Préhistoire Ariégeoise 42, 1987, 119-153.

BAHN P.G., COURAUD C. 1984 - Azilian pebbles: an unsolved mystery. Endeavour 8, 1984, 156-158.

COBLENZ W. 1993 - Die prähistorische Sektion der ISIS. Naturwissenschaftliche Gesellschaft Isis: Sitzungsberichte und Abhandlungen der Naturwissenschaftlichen Gesellschaft Isis, Dresden e.V. 1991/92, 1993, 35-38.

COBLENZ W. 2000 - Deichmüller als Senior der prähistorischen Forschung Sachsens. Naturwissenschaftliche Gesellschaft Isis: Sitzungsberichte und Abhandlungen der Naturwissenschaftlichen Gesellschaft Isis, Dresden e.V. 1995/96, 2000, 171-178. 
COURAUD 1985 - L'art azilien: Origine-survivance. XXème supplément à Gallia Préhistorique, Editions du CNRS, Paris175 p.

COURAUD C., ALTEIRAC A. 1990 - Les galets peints de la collection Roger. Préhistoire Ariégeoise 45, 1990, 187-199.

COURAUD C., ALTEIRAC A. 1993 - Nouveaux galets peints du Mas-d'Azil. Bulletin de la Société préhistorique de l'Ariège 48, 1993, 31-33.

COOK A. 1903 - Les galets peints du Mas d'Azil. L'Anthropologie 14, 1903, 655-660.

DRÖSSLER R., FREYBERG M. 2001 - Der Schweizer Archäologe Otto Hauser und die „Wissenschaftliche Privatsammlung Otto Hauser“ in Zeitz. Archäologie in Sachsen-Anhalt 1, 2002, 46-50.

GEINITZ H. 1882 - Über den gegenwärtigen Stand der prähistorischen Forschung in Frankreich und Deutschland. Sitzungsberichte und Abhandlungen der Naturwissenschaftlichen Gesellschaft Isis, 1882, 127-134.

GRAMSCH B. 2010 - Paläolithforschung in der ehemaligen DDR. Mitteilungen der Gesellschaft für Urgeschichte 19, 2010, 157-172.

GRIFFIN J.B., MELTZER D.J., SMITH B.D., STURTEVANT W.C. 1988 - A Mammoth Fraud in Science. American Antiquity 53, 1988, 578-582.

GROUPE d'Études Préhistoriques d'Elsterhorst 1950 - Le gisement d'Elsterhorst (Haute-Lusace) et la civilisation à caractère mésolithique de l'Elster et de la Sprée. Compte rendu de la XIIIe session du Congrès Préhistorique de France, Paris, 1950 (Paris 1950) 328-353.

HERRMANN E., KRABATH S., von BOXBERG I. 2013 - Eine biograpische Skizze zur ersten Archäologin Sachsens. In: J.-E. Fries/D. Gutsmiedl-Schümann (Eds.), Ausgräberinnen, Forscherinnen, Pionierinnen. Ausgewählte Portraits früher Archäologinnen im Kontext ihrer Zeit (Münster 2013) 29-42.

KEGLER J.F. 2007 - J. F. Kegler, Das Azilien von Mas d'Azil. Der chronologische und kulturelle Kontext der Rückenspitzengruppen in Südwesteuropa. Thèse université de Cologne (Köln 2007).

KRAFT I. 2010 - Paläolithikum und Mesolithikum. In: R. Heynowski/R. Reiß (Eds.), Atlas zur Geschichte und Landeskunde von Sachsen. Beiheft zur Karte B I 1.1-1.5 Ur- und Frühgeschichte Sachsens. (Dresde 2010) 12-23.

KRAFT I. 2014 - I. Kraft, Die Entdeckung der Tiefenzeit, In: : S. Wolfram (Eds.), In die Tiefe der Zeit. 300.000 Jahre Menschheitsgeschichte in Sachsen. Das Buch zur Dauerausstellung, Dresde 2014, 24-30.

LINDENSCHMIT L. 1876 - Ueber die Thierzeichnungen auf Knochen der Thayinger Höhle. Archiv für Anthropologie 9 1876, 173-179.

MALLERY G. 1893 - Picture-writing of the American Indians. $10^{\text {th }}$ Annual Report of the Bureau of Ethnology of the Secretary of the Smithsonian Institution 1883-1889, 1893, 822-1290.

MÉLARD N., KRABATH S. 2005 - Die erste Archäologin Sachsens: auf den Spuren von Ida von Boxberg. Archceo 2, 2005, 33-37.

PÉQUART M., PÉQUART S.J. 1936 - De l'authenticité des galets colorés du Mas-d'Azil et de leur signification présumée. Congrès international d'anthropologie et d'archéologie préhistoriques, $12^{\mathrm{e}}$ Session, Toulouse-Foix 548-558.

PIETTE E. 1895 - Études d'ethnographie Préhistorique I. - Réparation stratigraphique. L'Anthropologie 6, 1895, 275-292. 
PIETTE E. 1896 - Études d'ethnographie Préhistorique III. - Les galets coloriés du Mas d‘Azil. L'Anthropologie 7, 1896, 385-427.

PIETTE E. 1904 - Notions complémentiares sur l'Azilien. L'Anthropologie 14, 1903, 641-653.

SCHACHTMANN J. 2010 - Von der Prähistorischen Sammlung zum Landesmusum für Vorgeschichte: Die vorgeschichtliche Ausstellungen im Dresdner Wallpavillon. Archäologische Informationen 33, 2010, 59-68.

UNVERZAGT W., von JENNY W. 1935 - W. Unverzagt/W. von Jenny, Zehn Jahre Museum für Vorund Frühgeschichte 1924-1934. Berliner Museen 56, 1935, 2-15.

WELL 1926 - Scientific neglect of Mas D’Azil. Nature 118, 1926, 228.

WHITE 1992 - The history and research significance of the Logan Museum French Paleolithic collections. In: R. White, L. B. Breitborde (Hrsg.), French Paleolithic collections in the Logan Museum of Anthropology (Beloit 1992) 1-37.

\section{ABSTRACTS}

This contribution presents about 30 painted pebbles from Le Mas d'Azil which have been recently detected in the Staatliches Museum für Archäologie à Chemnitz (Germany). This study retraces the history of these pieces since their discovery at the site and demonstrates that they have been directly donated, in 1899, by the excavator Édouard Piette to the royal collection of prehistory at Dresden. The identification of their origin makes it unlikely that they represent forgeries and offer an important addendum to the existing inventory of these emblematic pieces of French prehistory.

INDEX

Keywords: painted pebbles, Le Mas d'Azil, Azilian, Édouard Piette, collections of Saxony

\section{AUTHORS}

\section{JOHANN FRIEDRICH TOLKSDORF}

Landesamt für Archäologie Sachsen, Projekt ArchaeoMontan, Zur Wetterwarte 7, D 01109 Dresden, JohannFriedrich.Tolksdorf@lfa.sachsen.de

\section{HARALD FLOSS}

Eberhard Karls Universität Tübingen, Abteilung Ältere Urgeschichte und Quartärökologie, D 72070 Tübingen,harald.floss@uni-tuebingen.de

\section{INGO KRAFT}

Landesamt für Archäologie Sachsen, Referatsleiter Ostsachsen, Zur Wetterwarte 7, D 01109 Dresden, ingo.kraft@lfa.sachsen.de 